\title{
A.15 University of Tokyo Library, Ms. $418^{32}$
}

A Nepalese paper manuscript of 279 leaves from 1864 CE (NS 984). In the final colophon it is called Dhāraṇīsaṃgraha-Purāṇa-Mahāyānasūtra. ${ }^{33}$

\section{Saptaśatikā-prajñāpāramitā 41r [163]}

2. Pañcaviṃśatikā-prajñāpāramitā-hṛdaya-nāma-dhāraṇī 43r [101]

3. Svalpākṣarā-bhagavatī-prajñāpāramitā-nāma-dhāraṇī 46v [164]

4. Bhagavatī-ardhaśatikā-prajñāpāramitā 49r [54]

5. Vajrasattvakāyasya tathāgatavyāptaśata $51 \mathrm{r}$

6. Sugatāvadānokta-saptabuddha-stuti 52v

7. Mūlavidyāmantrasiddhi-nāma-dhāraṇī 52v [1]

8. Vairocana-nāma-dhāraṇī 53r [3]

9. Akṣobhya-nāma-dhāraṇī 53r [4]

10. Ratnasambhava-nāma-dhāraṇī 53r [5]

11. Amitābhasya-nāma-dhāraṇī 53v [6]

12. Amoghasiddhi-nāma-dhāraṇī 53v [7]

13. Māyājālaṣodaśasāhasrikān mahāyogatantrāntaḥpātisamādhijālapaṭalād bhagavantas tathāgataśrīśākyamunibhāṣitā bhagvato mañjuśrījñānasattvasya paramārthā-nāmasaṃīti 64r [57]

14. Mañjuśrīpratijñā-nāma-dhāraṇī 64v [58]

15. Mañjuśrī-mantra-sūtra 65r

16. Amrtabhakṣā-nāma-dhāraṇī 65r [117]

17. Arapacanamañjuśrī sādhana-nāma-dhāraṇī 65r [123]

32 Available online: http://picservice.ioc.u-tokyo.ac.jp/03_150219 UT-library_sanskrit_ms/MF13 _50_003 MF13_50_003/?pageId=001 (accessed March 2020). Titles given with minor standardizations. Corresponding text numbers in Cambridge Ms. Add. 1326 are given in square brackets (there is a chance of inconsistencies in the case of texts which appear by the same title more than once). 33 Matsunami 1965: 148-149 reports on 275 folios. The dated colophon on folio 279 is given with minor corrections here: deyadharmo 'yaṃ pravaramahāyānayāyinaḥ paramopāsaka-paramadhārmika-śrī-vajrācārya-śrībhadra-pramukhādisagaṇānāṃ yad atra puṇyaṃ tad bhavat ācāryopādhyāyamātāpitṛpūrvagamanaṃ kṛtvā sakalasattvarāse 'nuttarasamyaksambodhipadaṃ prāptayanti | svasti-śrīmat-kāntipura-mahānagaranepāleśvara-mahārājādhirāja-rājendra-sakalarāja-cakrādhipatîsvara-śrīi-śrī-śrīsurendravikramamahādeva-paramabhaț̣āakadevānāṃ sadāsamaravijayināṃ prabhūthākulasya vijayarājye | dānapati-śrīmanta-sidhi-mahāvihāre tatavihāra-karadhukṣayā | gṛhāvasthita-śrī-vajrācārya-harașabhadranam ete sahānumatena idaṃ bhagavatạ̣ śrī-śrīśrī-dhāraṇīsaṃgrahapustaka likhitasampūrṇam sti | śreyo 'stu śubham | śubhasaṃvat 984 sti māghamāse śuklapakșasavantamiyāṃ tithe bharaṇinakșatre brahmayoge ādityavārasahare kumbharāśi gate bhāsakare meșarāśi gate candramasi | likhitaṃ kāntipuramahānagare. The rest is in vernacular. 
18. Maitreyapratijñā-nāma-sudhāraṇi 65v [87]

19. Maitreya-nāma-dhāraṇī $65 \mathrm{v}[18,124]$

20. Amoghapāśa-nāma-hṛdaya-mahāyānasūtra-nāma-dhāraṇī 75r [63]

21. Khasarpaṇā-nāma-dhāraṇī 75v [122]

22. Abhayaṃkarī-nāma-dhāraṇī 76r [72]

23. Sahasrabhujalokeśvarasya-nāma-dhārạ̣ī 76r [66]

24. Siṃhanādalokeśvara-nāma-dhāraṇi 76v [64]

25. Mokṣaprada-nāma-dhāraṇī 76v [71]

26. Āryāvalokiteśvarasya siddhinikā-nāma-dhāraṇī 77r [65]

27. Ṣaḍakṣarī-mahāvidyā-nāma-dhāraṇī 78r [69,139]

28. Avalokiteśvarasya nīlakaṇṭha-hṛdaya 79r [67]

29. Padmahasta-nāma-dhāraṇi 79v [17]

30. Sahasrāvartā-nāma-dhāraṇī 80r [68]

31. Prathamākṣarasaptamiśraṇasamyuktaṣaḍakṣara-stava 81r

32. Cintāmaṇilokeśvara-nāma-dhāraṇī 82v [33,109]

33. Sarvalokeśvara-nāma-dhāraṇī 82v [121]

34. Eka-nāma bhagavanta āryāvalokiteśvarasya așțottaraśata-nāma-mahāyānasūtra 85v

35. Kāraṇḍavyūhokta-dharmarāja-stuti 86v

36. Kāraṇḍavyūhokta-umāmaheśakṛta-stava 87r

37. Śrīvajradattaviracita-śrīlokeśvara-śataka 101v

38. Sarvadurgatipariśodhanarājasya tathāgatasyārhatạ̣ samyaksambuddhasya kalpaika 109v [48]

39. Așțamahābhayapungala-nāma-dhāraṇī 110r

40. Viśvamātā-nāma-dhāraṇī 110r

41. Atītā-nāma-dhāraṇī 110v

42. Śākyamuni-nāma-dhāraṇī 110v [32]

43. Caṇụamahāroṣaṇatantrāntapaṭala $111 \mathrm{v}$

44. Ekallavīra-nāma-samādhi-hṛdaya $112 \mathrm{v}$

45. Mantraphaladā-siddhidāyanī-vajrayoginīnairātmāguhyeśvarī-mantranāma-dhāraṇī 114v

46. Daśakrodha-nāma-dhāraṇī 115r [114,128]

47. Jāngulì-hṛdaya-nāma-dhāraṇī 115r

48. Ușṇīṣacakravartī-nāma-dhāraṇī 115v [50]

49. Vajrayoginī-nāma-dhāraṇī 116v [159]

50. Ekajațā-nāma-dhāraṇī 123v [113]

51. Prajñāpāramitā-stuti $124 \mathrm{~V}$

52. Prajñāpāramitā-dhāraṇī $124 \mathrm{v}[8,56]$

53. Șaṭpāramitā-hṛdaya-nāma-dhāraṇī 125r [59]

54. Ratamālikā-nāma-dhāraṇī 125v 
55. Vasudhārā-nāmāṣțottaraśata-buddhabhāṣita 127r [97]

56. Vajravidāriṇī-hṛdaya-mūlamantra-dhāraṇī 128v [98]

57. Gaṇapati-hṛdayā-nāma-dhārạ̣ī 130r [99]

58. Gaṇeśaṣoḍaśa-nāma 130r

59. Uṣṇịsavijayā-nāma-dhāraṇī 131v [100]

60. Parṇaśavarī-mahāmārīparṇaśavarī-nāma-dhāraṇī 132r [85]

61. Mārīcī-nāma-dhāraṇī 133r [102]

62. Grahamātṛkā-nāma-dhāraṇī 139r [103]

63. Rāhuvyagrahaśānti-upadrava-nāma-dhāraṇī 140r

64. Ketugrahaśānta-nāma-dhāraṇī 141v

65. Śrīmat-vighnāntaka-stotra $141 \mathrm{v}$

66. Mahāsarasvatī-nāma-dhāraṇī 142v [94]

67. Bṛhaspatikṛtavāgvādinī-stotra 143r

68. Vajratārā-nāma-dhāraṇī 143r [126]

69. Cūọā-nāma-dhāraṇī 143v

70. Jambhalajalendrasya-nāma-dhāraṇī 144r [61]

71. Ugratārā-nāma-stotra $145 \mathrm{r}$

72. Caturyogadevadevī-nāma-dhāraṇī 145r

73. Buddhabhațțārakasya-nāma-dhāraṇī 145r [34,119]

74. Prasannatārāya-nāma-dhāraṇī 145v [132]

75. Așțamahābhairava-nāma-dhāraṇī 145v

76. Siddhivighneśvara-nāma-dhāraṇi 146r [134]

77. Tathāgataguhyakā-nāma-dhāraṇī 146r [14]

78. Kurukullā-nāma-dhāraṇī 146v [95]

79. Mahāmeghanirnādavijụmbhitasuraketu-nāma-dhāraṇī sarvabuddhabhāșita 151r

80. Mahāmeghād mahāyānasūtrād vātamaṇḍalīparivarta-pañcașaștitama 157r

81. Vairocaṇīdevī-stava-stotra $157 \mathrm{r}$

82. Suvarṇaprabhokta-sarasvatīśata-nāma-stava 158r

83. Suvarnaprabhokta-sarasvatī-stotra $158 \mathrm{v}$

84. Suvarṇaprabhokta-kamalākarasarvatathāgata-stava 161r

85. Dvādaśākṣaramūla-nāma-dhāraṇī 161r

86. Padmottama-nāma-dhāraṇī 161v

87. Samyaksambuddhavairocanabhāṣita bhagavatyai āryatārādevyā namaskāraikaviṃśati-nāma-stotra 163r

88. Mahākālasya-nāma-dhāraṇī 163r [135]

89. Caturbhujamahākāla-sādhana-nāma-dhāraṇī 163r

90. Ṣaḍbhujamahākāla-sādhana-nāma-dhāraṇī 163v

91. Dvādaśabhujamāhākāla-sādhana-nāma $164 \mathrm{r}$

92. Skandapurāṇe śaniścaradvādaśa-nāma 164r [180] 
93. Candradvādaśa-nāma-stava 164v

94. Vaiśramanakuvera-stava $164 \mathrm{~V}$

95. Ādityadvādaśasūrya-nāma-dhāraṇī 168r [111]

96. Hanumanta-hṛdaya-nāma-dhāraṇi 169v

97. Vajrasattva-nāma-hṛdaya 169v

98. Tṛtīyakallavīrasya-nāma-hṛdaya-dhāraṇī 169v

99. Dveșavajrī-hṛdaya-nāma-dhāraṇī 170r

100. Yogāmbarasya mantra-hṛdaya-dhāraṇī 170r

101. Herukasya samādhi-hrdaya 170v

102. Hevajrasya mantra-hṛdaya-nāma-dhāraṇī 170v

103. Vajravārāhī-mantra-hṛdaya-nāma-dhāraṇī 171v

104. Vajrabhairavakālacakrasya mantrahṛdaya-nāma-dhāraṇī 173r

105. Bhṛkutịtārā-nāma-dhāraṇī 173v

106. Halāhalalokeśvarasya hṛdaya-nāma-dhāraṇī 174v

107. Bhagavān-lalitavistaro-nāma-dhāraṇī 176v [15?]

108. Vajravīrāsinī-nāma-dhāraṇī 177r

109. Cakrasamvarasya tantrāntapaṭala-hṛdaya 178r

110. Vajraḍākinī-hṛdaya-mantra-nāma-dhāraṇī 179v

111. Așțậākinī-hṛdaya-nāma-dhāraṇī 179v

112. Herukasya sarvarogapraśamanī-nāma-dhāraṇī 180v [144]

113. Vidyādharīdevyopahṛdaya-dhāraṇī 181r

114. Vajravārāhī-hṛdaya-mantra-dhāraṇi 181v

115. Pratisarāyā kalpa 182r

116. Pratisarā-stotra 182v

117. Mahāpratisarā-mahāvidyā-dhāraṇī 188v [76]

118. Pratisarā-kalpa-dhāraṇī 191r [77]

119. Mahāsāhasrapramardanī-nāma-vidyā-dhāraṇī 203v [78]

120. Mahāmāyūrī-vidyārājñī-nāma-dhāraṇī 217r [79]

121. Mahāśītavatī-nāma-vidyā-dhāraṇī 219r [80]

122. Mahāmantrānusāriṇi-mahāvidyā-nāma-dhāraṇī 221v [81]

123. Vasudhārā-nāma-dhāraṇī 222v [82]

124. Yakșāșțaka-samyaksambuddhabhāṣita 223r [60]

125. Jambhalajalendrasya-nāma-dhāraṇī 223v [61]

126. Vasudhārā-nāmāṣțottara-buddhabhāṣita 237v [97]

127. Dhvajāgrakeyūrī-nāma-dhāraṇī 239r [90]

128. Tārāśat-nāma-mahāyānasūtra 239v

129. Sarvatathāgatasitātapatrā-nāmāparājitā-mahāpratyaṅgirā-vidyārājñ̄i 241v [83]

130. Aparimitāyur-mahāyānaśūtra 242r [47]

131. Sapaneya-vidyā-nāma-dhāraṇī 242r [84] 
132. Saddharmalañkāvatāra-mahāyānasūtra 243v [12]

133. Suvarṇaprabhāsottama-sarvabuddhabodhisattva-nāma-dhāraṇī 243v [16]

134. Sarvatathāgatām śatākṣarāṇi $244 \mathrm{r}$

135. Gaṇeśaṣoḍaśa-nāma-dhāraṇī 244r [136]

136. Bhadracari-praṇidhānaratnarāja 248r [70]

137. Cakrasamvara-mahāyoga $248 \mathrm{v}$

138. Vajravārāhī-mahāyoga 248v

139. Kālikā-stava 249v

140. Piṭhāṣțaka-stotra-sampūrṇa 253r [178]

141. Tārābhaț̣ārikāyāḥ sragdharā-stuti 257v

142. Mahābhairavatantre viparītapratyaṅgirā 259r

143. Viparītapratyañgirā-nāma-dhāraṇī 259v

144. Guṇakālavibhu-nāma-dhāraṇī 261v

145. Kālavibhu-mahāyānasūtra 261v

146. Sūrya-stotra $262 \mathrm{v}$

147. Divākaramahāmantre sūryāvatārasūryaśānti-stava-stotra 264v

148. Yamāntakasya hṛdaya-dhāraṇī 265r

149. Prajñāntakasya hṛdaya-nāma-dhāraṇi $265 \mathrm{r}$

150. Padmāntakasya hṛdaya $265 \mathrm{v}$

151. Vighnāntakasya hṛdaya 266r

152. Mahāvara-hṛdaya 266r

153. Acala-hṛdaya $266 r$

154. Takkirājasya hṛdaya $266 \mathrm{v}$

155. Nìladaṇdasya hṛdaya $266 \mathrm{v}$

156. Ușṇīṣacakravatisya hṛdaya $266 \mathrm{v}$

157. Sambharāja-hṛdaya-mahāmantra-dhāraṇī daśakrodhamantrasiddhi 266v

158. Krodha-hṛdaya-mantra-dhāraṇī 267r

159. Dhvajāgrakeyūrī-nāma-dhāraṇī 268r [90]

160. Jambhalajalendrasya-nāma-dhāraṇī 269r [61]

161. Dhvajāgrakeyūrī-mantra-hṛdaya-dhāraṇī 269r

162. Saṃyaksambuddhavairocanabhāṣita bhagavatyāryatārādevyā namaskāra-ekaviṃśati-nāma-stotra 270r

163. Nairātmāyoginīsarvadhyātmakadhyāna-mantra-dhāraṇī 271r

164. Svayambhū-purāṇa $271 \mathrm{r}$

165. Bhìmasena-stotra $273 \mathrm{r}$

166. Megha-dhāraṇī 273v

167. Mañjuśrīpratijñā-nāma-dhāraṇī 273v [58]

168. Șoḍaśabhujamahākāla-sādhana 275v

169. Simghamukhi-nāma-hṛdaya $276 \mathrm{v}$

170. Siṃghamukhi-nāma-dhāraṇī 278v 